\title{
PRIVATE SECURITY IN REPUBLIC OF MACEDONIA IN PROVIDING SAFETY IN URBAN AREAS
}

\author{
Marjan Nikolovski, PhD \\ Faculty of Security - Skopje \\ E-mail: mnikolovski@fb.uklo.edu.mk \\ Borce Petrevski, MSc. \\ Ministry of Interior Affairs, Republic of Macedonia \\ E-mail: borcepetrevski@yahoo.com \\ Predrag Micevski, MSc. \\ Private detective, Macedonia \\ E-mail: pepi.micevski@yahoo.com
}

\begin{abstract}
The transformation of the socio - political and economic system in the countries in transition, including the Republic of Macedonia, the past years have led to radical changes in the socio-economic relations, when private property gained dominant form and gradual decentralization of certain responsibilities from public to private security have happened.

The segments of the private security subsystem (PSS), respectively the security agencies of persons and property and the detectives with their position in the security ambient, are gaining significant place and role in the maintaining of the overall security, with which they have important contribution in the successful security and the security of urban areas in one modern country, especially in its preventive function.

The data that so far the Ministry of Interior (Mol) in the Republic of Macedonia has issued a total of 203 work permits for private security and 40 permits for technical security, issued 154 permits for providing for their own needs, and 91 legal person performing secured by giving services and that are registered and operate eight private detectives, suggest that
\end{abstract}




\section{Securiaty}

there is progress in the development of this security subsystem in the country, which despite some shortcomings, began to develop significantly in the last fifteen years.

Generally, the activities of the subjects of the subsystem of private security in the country, have a positive contribution to security in our country and ensuring greater security in urban areas, complementing the police in certain activities, so that today, despite the physical and technical security, the activities of agencies and detectives are directed towards preventing and combating specific manifestations of organized crime, including insurance fraud, violations of intellectual property rights, resolve certain cases related to thefts of vehicles, etc.

The current global trend of increasing progress and development of the subsystem of private security, contrary to the need for greater security in urban areas require prevention and elimination of harmful effects caused by newer and more sophisticated techniques, as well as permanent adjustment and construction of a modern security system (in this direction and subsystem of private security), by finding an opportunity of improving his concept and proactive contribution towards effectively prevention and combating crime in general.

Keywords: security system, private security, private security agencies, detectives, security in urban areas

\section{Introduction}

Dynamic social life and the challenges and needs of the modern age, determined starting "a process of privatization" of security features in the systems of countries around the world, thus increasing the overall national security. It implied gradual transfer of certain jurisdictions (transfer of certain services) from the public to the private security, which influenced on a transformation of the security system of the country (SSC), as well as establishing a new private security subsystem (PSS) with a primary preventive function and directed primarily to personal protection and protection on property of citizens.

Private Security Agencies (PSA) and detectives as particular segments of private security subsystem (PSS) in the Republic of Macedonia with its position in the security environment, gaining more important place and role in maintaining overall security, and thus they have an important role in successful prevention and combating of certain forms of organized crime in a modern state, especially in its preventive function. 
Undoubtedly that all entities that make up the security systems have their place and role, but fully balanced in an integral modern safety concept, they can respond today's security challenges, threats and dangers.

\section{Private security}

Private security implies planned, organized and legally based, independent or joint activity and function of individuals, companies, private and / or professional agencies, aimed at their own protection or the protection of others and the protection of relevant persons, space, facilities, operations or activity, which are not covered by the exclusive protection of the public authorities, as main targets have the elimination of potential threats to persons, damage, destruction or unauthorized usurpation of property, by proactive action - with methods of analysis and timely prevention, as well as reactive action - through prevention and rehabilitation of consequences, creating safe conditions for more stable and more efficient working of the companies, with aim to increase their profits. In addition, unlike SSC, whose role is repressive and preventive, PSS is primarily preventive oriented.

Having in mind that so far in Republic of Macedonia the Ministry of Interior (Mol) has issued a total of 203 work permits for private security and 40 permits for technical security, issued 154 permits for providing for their own needs, respectively 91 private security agencies are engaged in giving security services, and that there are eight registered private detectives, we can say that there is a progress in development of this security subsystem in Republic of Macedonia, which, despite some shortcomings, began significantly developing in the last fifteen years.

PSS in Republic of Macedonia.Legal norms covering this issue are located in: the Constitution of Republic of Macedonia, the Criminal Code, the Criminal Procedure Code, the Law on Internal Affairs, the Law on Police, Private Security Act, the Law on detective action, the Law on Weapons, the Law on protection and rescue, firefighting Act, Statute of the Chamber of Republic of Macedonia for private security, and other sub-law acts in the field of private security and detective services.

Subjects of PSS in Republic of Macedonia are: PSA (as security agencies of persons and property registered for giving services or for personal needs), Chamber of Republic of Macedonia for private security, detectives and Mol.

1. Private security agencies (PSA) for providing services is registrated for regular operations by typing a business in the Central Register of RM and given permission, which is 


\section{Seculabrity}

valid for theprivate security agencies for personal needs, too. It's necessary, besides the general conditions, some specific conditions to be fulfilled:

a) a legal entity that provides services as physical security - it should have at least 15 workers with licenses for physical security, a certificate from the Chamber that workers don't possess valid identity cards for physical security, designated responsible person, it should owns act on systematization of jobs (with description of authorizations for each job/working place), it should posses own act of working clothes and sign of the legal entity, it should have business office and at least two vehicles;

b) legal entity that provides services as tehnical security - at least three workers with licenses for technical security, a certificate from the Chamber that workers don't possess valid identity cards for technical security, designated responsible person, act on systematization of jobs, act on the working clothes and sign of the legal entity, business office and at least two vehicles;

c) for legal entities engaged in providing security for their personal needs - at least ten employees with licenses for physical security, a certificate from the Chamber that workers don't possess valid identity cards for physical security, act for systematization of jobs, act on the working clothes as well as business office.

2. Chamber of Republic of Macedonia for Private Security was established in June 2000, whose activity is directed towards the successful organization of private security, protection and improvement of professional competences, professionalism and business, as well as the protection of the profession. In the period of 2006-2010, the Chamber of security of people and property and detective services - "Detective Skopje" functioned and issued security licenses without obtained approval from the Mol.

3. In Republic of Macedonia, detective activity can perform only detective who obtained a license for detectives, issued by Mol. According to available data, for this type of activity so far in our country are issued 8 licenses for private detectives.

4. The control and supervision of PSS is in charge of Mol. The administrative - legal supervision is authorization of the Department of weapons, explosives and hazardous materials, as a part of Unit of Administrative Affairs at the Sector of Internal Affairs - Skopje (which Department is hierarchal subordinated by the Unit for security agencies, detective work and issuing approvals and permits for weapons in the Sector for weapons, explosives and dangerous materials, security agencies and detectives in the Department of civil Affairs in the Ministry of Interior), while the cases of overdrawing of authorities by the employees in PSS are responsibility of the regional police stations (PS). Authorized officials in the Ministry of Interior are in charge of following activities of supervision: whether and how to implement the law and 


\section{Seccurity}

regulations, check the records of the contracts, review of business offices, technical facilities, devices and vehicles, checking the manner of keeping and carrying of firearms, handling ability, and how the authorities are used.

\section{Security in urban areas and PSS in Republic of Macedonia}

In Republic of Macedonia, the activities of private security agencies in urban areas are in field of physical and technical security of big industrial buildings, residential complexes, shopping and sports facilities, warehouses and other storage areas, residential and other buildings, as well as installing control alarm systems, sensors for monitoring, access control facilities, intervention in case of fire, defects, etc.

On the other hand, private detectives are focused on collecting information on stolen and lost items, missing and hidden persons, insurance fraud (mostly in cases of vehicles), resolving cases of theft of luxury vehicles, violation of rights of intellectual property, checks the creditworthiness of private companies, etc.

In this way, the subjects of private security subsystem positively contribute and provide greater security in urban areas, especially in aiding of the police services in our country. All this, in terms of increased security threats, strengthens the perception and feelings of greater security.

PSS situation in other countries. Conditions of development of PSS in Serbia and Kosovo do not differ significantly, which is not the case with Croatia, Slovenia, Germany, and especially Canada, where the activities of PSS include private and criminal investigations, as well as activities of corporate security.

In highly developed countries, PSS has its responsibilities and charges in investigations of committed crimes, and their activities overlap with the activities of the police. In fact, a growing number of detective agencies offer services of operational action and clarification of criminal acts prosecuted ex officio, and private investigators often determine the reliability of the evidence in police working, help in finding witnesses, gathering evidence in favor of defense, etc.

In this sense, Gill and Hart believe that the activities of private investigators pose a direct competition to the criminal police and private detectives, but also they indicate that if these subjects with their parallel investigations adhere to the law, they are not a competition, but only in function of determination the truth. 


\section{Securiaty}

Collaborative models and relationships. In the era of modern living and new security challenges, it has recorded a growing collaboration between the subjects of State security sistem and PSS, in the field of prevention of new forms of crime and terrorist threats. Private security activities often appears as "extensional activities" of the police and other state authorities, especially due to the fact that employees of private security agencies are present in areas that might be interest for criminal and terrorist acting.

In the context of cooperation between the two entities, there are observations that it is most effective in the fields of control of "white collars" crime and corporate crime. Formerly, Director of FBI, William Webster directed the FBI capacities towards to PSS, arguing that "private security industry serve the business" and that "it is at the forefront," where corporate crime occurs, also appealing for aid in function of the public security by participation ofPSS.

Therefore, the optimal way of response to security challenges is coordinated, timely and open cooperation in terms of globalization when mutual dependence between global and local security problems is the greatest, and the links between the one and the other aspect is almost unbreakable.

\section{Results of the conducted research}

In the context of the role of the subjects of private security subsystem in Republic of Macedonia in achieving greater safety and security of citizens and property, will be presented part of the results of empirical research conducted in 2010, realized in 9 towns in Republic of Macedonia.

The survey was done with an aim of anticipation of the role of subjects of private security subsystem in Republic of Macedonia in ensuring the safety of citizens and their property, the views expressed by the different categories of respondents, the level of customer satisfaction with the services of private security agencies and the need for transferring some of responsibilities from the Ministry of internal Affairs to Agencies.

The sample has been consisted of 253 citizens, 123 recipients of services, 20 managers of agencies, 2 presidents of Chambers for private security and 2 representatives of the Ministry of Interior engaged in monitoring the agencies' functioning. 


\section{Securiaty}

What do you think about the role of private security subsystem from perspective of safety and security of citizens and their property?

\begin{tabular}{|l|c|c|c|c|c|c|}
\hline \multirow{2}{*}{} & \multicolumn{2}{|c|}{ Managers } & \multicolumn{2}{c|}{ Chamber } & \multicolumn{2}{c|}{ Mol } \\
\cline { 2 - 7 } & $\mathrm{f}$ & $\%$ & $\mathrm{f}$ & $\%$ & $\mathrm{f}$ & $\%$ \\
\hline Greater security & 17 & 85 & 1 & 50 & 2 & 100 \\
\hline Not affect & 3 & 15 & 1 & 50 & - & - \\
\hline Total & 20 & 100 & 2 & 100 & 2 & 100 \\
\hline
\end{tabular}

For a positive impact of private security from the perspective of overall security reported $85 \%$ of managers, one president of the Chamber, as well as two representatives of Mol. A high percentage of the three groups of respondents estimated that private security on today's level of it's development generally has positive influence on the improvement of the security of citizens and the security of their property.

How a private security affects the security of citizens?

\begin{tabular}{|l|c|c|}
\hline \multirow{2}{*}{} & \multicolumn{2}{|c|}{ Citizens } \\
\cline { 2 - 3 } & $\mathrm{f}$ & $\%$ \\
\hline Positively impact & 121 & 47,83 \\
\hline Has partial impact & 92 & 36,36 \\
\hline Negative impacts & 23 & 9,09 \\
\hline I am not sure & 17 & 6,72 \\
\hline Total & 253 & 100 \\
\hline
\end{tabular}

From the total number of people included in the survey, $84.19 \%$ of respondents believe that the activities of the subjects of private security subsystem has full or partial positive impact on the security of citizens, and their negative attitude is about: unsettled of that field, the low level of development and quality of service, unfair competition, problems with operating and management, insufficient staff training, provision of services only "unform", and all that, particularly in relation to low prices of the services and the standard in our country. 
Do you feel safer and more secure since you started to cooperate with the private security agencies?

\begin{tabular}{|l|c|c|}
\hline \multirow{2}{*}{} & \multicolumn{2}{|c|}{ Service users } \\
\cline { 2 - 3 } & F & $\%$ \\
\hline I feel completely safe & 91 & 73,98 \\
\hline I feel partially safe & 26 & 21,14 \\
\hline I do not feel safe & 3 & 2,44 \\
\hline I feel more insecure & 1 & 0,81 \\
\hline Unanswered & 2 & 1,63 \\
\hline Total & 123 & 100 \\
\hline
\end{tabular}

The highest percentage of citizens (74\%) reported that in cooperation with private security agencies, namely the use of their services makes them feel more secure. The fact that a person or object is under the care of a specialized security agency acts preventively against potential violators of safety and security of persons and objects and depart them far away from their intentions. The answers of first two oppiniances shows that $95 \%$ of citizens who use the services of private security agencies are satisfied and feel fully or partially safe. Citizens who said that they don't feel safe, are only $2.44 \%$. According to the opinion of citizens, private security agencies have justified their existence because the citizens feel more secure and their engagement facilitates the work of the police, that they focus on solving more sophisticated crimes.

What is a grate of yours satisfaction on the quality of services you receive from private security agencies regarding your own security and the security of your property?

According the opinion of the users of the services, generally they are satisfied with the agencies's services, primarily because of their professionalism, expertise in handling, storage of the working secret, as well as significant material - technical competence, which are important conditions for providing quality services in the field of private security. 
Secculabrity

\begin{tabular}{|c|c|c|c|c|c|c|c|c|c|c|c|c|}
\hline \multirow{3}{*}{$\begin{array}{l}\text { Service } \\
\text { features }\end{array}$} & \multicolumn{12}{|c|}{ Service users } \\
\hline & \multicolumn{2}{|c|}{$\begin{array}{c}\text { very } \\
\text { pleased }\end{array}$} & \multicolumn{2}{|c|}{ contented } & \multicolumn{2}{|c|}{$\begin{array}{l}\text { partially } \\
\text { satisfied }\end{array}$} & \multicolumn{2}{|c|}{$\begin{array}{c}\text { somewhat } \\
\text { satisfied }\end{array}$} & \multicolumn{2}{|c|}{ Unsatisfied } & \multicolumn{2}{|c|}{ Total } \\
\hline & $f$ & $\%$ & $f$ & $\%$ & $f$ & $\%$ & $f$ & $\%$ & $f$ & $\%$ & $f$ & $\%$ \\
\hline Professionalism & 64 & 52,03 & 49 & 39,84 & 7 & 5,69 & 1 & 0,81 & - & - & 123 & 100 \\
\hline cost of service & 45 & 36,59 & 60 & 48,78 & 17 & 13,82 & - & - & 1 & 0,81 & 123 & 100 \\
\hline $\begin{array}{l}\text { storage of the } \\
\text { working secret }\end{array}$ & 75 & 60,98 & 42 & 34,15 & 3 & 2,44 & 1 & 0,81 & 2 & 1,63 & 123 & 100 \\
\hline $\begin{array}{l}\text { expertise in } \\
\text { handling }\end{array}$ & 67 & 54,47 & 50 & 40,65 & 4 & 3,25 & - & - & 2 & 1,63 & 123 & 100 \\
\hline $\begin{array}{l}\text { material and } \\
\text { technical } \\
\text { equipment }\end{array}$ & 56 & 45,53 & 52 & 42,28 & 8 & 6,50 & 2 & 1,63 & 5 & 4,07 & 123 & 100 \\
\hline $\begin{array}{l}\text { attitude } \\
\text { towards the } \\
\text { customer }\end{array}$ & 68 & 55,28 & 40 & 32,52 & 4 & 3,25 & 1 & 0,81 & - & - & 123 & 100 \\
\hline overall working & 62 & 50,41 & 55 & 44,72 & 5 & 4,07 & 1 & 0,81 & - & - & 123 & 100 \\
\hline
\end{tabular}

Do you think that part of the responsibilities of the Ministry of Interior should be transferred to the private security agencies?

\begin{tabular}{|c|c|c|c|c|c|c|}
\hline \multirow{2}{*}{} & \multicolumn{2}{|c|}{ Managers } & \multicolumn{2}{c|}{ Chamber } & \multicolumn{2}{c|}{ Mol } \\
\cline { 2 - 7 } & $f$ & $\%$ & $f$ & $\%$ & $f$ & $\%$ \\
\hline Yes & 10 & 50 & 2 & 100 & 2 & 100 \\
\hline No & 10 & 50 & - & - & - & - \\
\hline Total & 20 & 100 & 2 & 100 & 2 & 100 \\
\hline
\end{tabular}

Regarding the idea for contemporary concept of security, part of the jurisdiction of $\mathrm{MOI}$ to be transferred in the security agencies of persons and property, there is a divided opinion among the managers. The representatives of and Presidents of Chambers fully agree with this idea. The positive attitude is explained with the need of the MOI to be oriented towards discovering and solving serious crimes, while the security agencies of persons and property will be more efficient in money transport, patrol work, constant supervision of the objects through monitoring center, securing public manifestations and some public 


\section{Securiatity}

institutions and objects. The negative attitude goes with the explanation that the security agencies of persons and property still have not reached the necessary level for quality performing of these activities because of lack of order, discipline, hierarchy, competences, higher criteria, law regulation, efficient control and opportunity for maltreatment during reciprocal calculation.

Part of the problem of the conflict lies in the fact that in cases of unprofessional conduct and insufficient engagement of individual employees in agencies (eg. acts in burglary, robbery, armed robberies or other criminal activity), it ends with the treatment and intervention of police. In such cases, the police further engage and efforts are made to address the issues associated with "poor" performance of the agencies.

\section{Discussion}

The bigger part of the respondents consider that the security agencies of persons and property primarily perform their preventive role in the public security successfully, so that they take minimum responsibilities of patrol activity, which was performed by local police stations, which lowers the state costs. The security agencies of persons and property enable higher level of protection, especially of the property, which the police is not able to cover. Here upon, a special role has the patrol security which regularly goes round the objects, and that objectively lowers the crime and draws higher response and trust among the citizens. Certain security agencies of persons and property have reached high level of development and quality of the services, but the non - existence of standards lowers the price, the salaries and possibilities for training the employees. In the last fifteen years, PSS developed rapidly, but the benefit is expected later.

However, PSS to the level to which is developed until now, it can be concluded that it has a positive impact of increased security of citizens and their property (85\% of managers and representatives of the Mol) and of a sense of security of citizens $(84,19 \%)$ and recipients $(95,12 \%)$. However, there is insufficient clear in the majority of citizens and the Mol about the role of PSA in total safety, so many of them are seen as uneducated, "hair-cut" guys who carry weapons and "pose a threat to security" and $53,76 \%$ of citizens believe that workers in providing PSA choose their profession because they have no other choice. This is an indication of lack of promotion of this activity in front of the public in RM or insufficient development of PSS, according to market needs, on which have to work. 


\section{Sececurity}

\section{Perspectives of private security in Republic of Macedonia}

According presented results, in the future is expected PSA to be engaged in providing security in governmental institutions, National bank of RM, embassies, diplomatic- consular representative, firms, juveniles, children's residential homes, depots, airports, railway stations, forests, national parks etc., as well as conducting minor investigations because they have more frequent contacts with the citizens. In addition Mol will only control and give suggestions, and will be released from certain, to them, "inessential activities, due to which the competitive attitude will stop and the efficiency of the two segments will increase. With the utilization of that model, we can talk about the private security system as integral subsystem of the whole security system of one democratic society. Some of the respondents with positive attitude consider that, after all, certain vital objects should remain under jurisdiction of Mol, due to higher state interest. In this sense, also we can expected to: consolidation of this subsystem (65\% of managers and representatives of Mol), privatization of certain aspects of security ( $50 \%$ of managers, president of Chambers and representatives of $\mathrm{Mol}$ ), and in addition to opening this market to foreign capital there is a dual attitude (except the representatives of Mol, which is entirely negative).There is also lack of awareness about the need of cooperation between PSA and insurance companies, primarily among managers of insurance agencies, as well as the representatives of Mol, so between the two segments at this point there is a competitive relationship.

The assessment is that in general, the activities of the subjects of the private security subsystem in RM in the future also will have positive contribution to the security in our country, complementing the police in certain activities, so that at this point, apart from the activities of the security agencies of persons and property related to the physical and technical security of persons and property will be directed towards successful security of urban areas in one modern country, especially in its preventive function. The activities of private detectives will grow, especially in the field of fighting against certain forms of organized crime, including the security frauds, violation of the laws of intellectual property, solving certain cases connected with vehicles theft, etc.

\section{Conclusions}

The constant global trend of higher and higher development of the private security subsystem, against the need for prevention and removal of harmful consequences caused by 


\section{Seccurity}

the newer and more sophisticated techniques, require permanent adjustment and building of a modern security system (in this direction a private security subsystem as well), through creating a possibility for promotion of its concept in the successful security and of the security in urban areas and more active contribution in direction of successful restraining and repressing the crime.

The cooperation between the private security and the state safety sector as an integral security system, in function of the modern security concept, requires permanent, sincere, and partner relationship for successful performance of the security function, where upon mutual promotions are needed in the raising of the conscience of the members of the two segments and the population in general. In that contexts, there is a need for precise definition of the forms and methods of cooperation between the subjects of the private security subsystem and the police, and especially the way of communication and fast exchange of information, are important conditions in the direction of more adequate preventive repressive position and functioning of this security segment. So, the organization and functioning of the modern security system implies its permanent adjustment and rebuilding as a response to the new security challenges, threats, risks, and endangering, for their prevention and removal of the harmful consequences.

\section{References}

1. 1.Bailey, W.G., (1989). The Encyclopedia of Police Science. NewYork. Garland

2. 2.Connolly, Charles P., The role of Private security in Combating terrorism, the Major Cities Chiefs/National Executive Institute's Annual Conference. sun Valley. Idaho.www.neiassociates.org/privatesecurity.htm.

3. 3.Dobovšek, Bojan, (1996). Organised crime - can we unify the definition?, in: Policing in Central and Eastern Europe: Comparing firsthand knowledge with experience from the west. College of Police and Security Studies. www.ncjrs.gov/policing/org323.htm.

4. Dobranović, Ž.Mihaljević, B., (2007). Privatna zaštita u normi i praksi. Veleučičište Velika Gorica

5. 5.Герасимоски С. (2008).Приватната безбедност во услови на глокализација. Годишник на Факултетот за безбедност. 2007/2008

6. 6.Cill, M. and Hart, J. (1997).Exploring investigative policing - A Study of Private Detectives in Britain. British Journal of Criminology. Vol.36, No.4 
7. 7.Hakala, J., Why regulate manned private security? Internet.http://coess.org/ studies.htm.

8. Petrevski, B., (2010) The authorities of subjects of private security in the Republic of Macedonia-factor for the safety of citizens and their property. Master's thesis. Skopje. Faculty of Security

9. Report of the seminar Public-Private Partnership (PPP) held on 16 and 17 December 2002 in the Hague. www.coess.org/documents/seminar publicprivate partnership.pdf.

10. 10.Shearing, C., (2008). Nodal Governance, Democracy, and the New 'Denizens.Journal of Law and Society. Cardiff University law school. Vol. 30. Issue 3

11. 11.Schneider, Stephen R., (1998).Combating Organized Crime in (and by) the Private sector: A Normative role for Canada's Forensic Investigative Firms. Journal of Contemporary Criminal Justice. Vol. 14. No. 4

12. 12.Stajić, Lj. (2008). Osnovi sistema bezbednosti. Novi Sad. Pravni fakultet 